\title{
РУСИНИ У ВОЈВОДИНИ - УСТАНОВЕ КУЛТУРЕ
}

\section{Сажетак}

Преко 250 година Русини живе заједно или једни поред других са Србима и другим нацијама на територији данашње Војводине. У раду сазнајемо како се формирао културни и национални идентитет Русина у Војводини кроз оснивање и рад установа културе, образовања и религије. Презентовани су и историјски подаци о пореклу Русина, досељавању у тзв. „нови крај“ и њихово прилагођавање животу у плодној равници.

Кључне речи: Русини, Војводина, историја, установе, култура, образовање, религија, национални идентитет

Преко 250 година Русини живе заједно или једно поред другог са Србима у Војводини. За суживот је то сасвим довољан број година да потврди да су се односи ова два словенска народа од почетка развијали у смеру толеранције, добросусетских и коректних односа, заједно делећи често злехуду судбину малих народа на овим просторима кроз све светске и локалне ратове, и разне облике владавине од аустроугарске царевине, преко краљевине, републике, до садашњег транзиционог периода. Ни за једно историјско раздобље се не може рећи да је било лако, увек је било изазова али војвођански Русини, као народ без своје матичне земље и државотворних обележја, су успели да у благонаклоној средини сачувају и изграде свој идентитет, и религију, кодификују језик, пишу књиге, издају часописе, имају школовање на матерњем језику и студије русинистике, као нигде другде на свету. Дакако, да има још простора за активнију културну, лингвистичку и књижевну промоцију у доминатној српској средини, поготово изван „граница“ Војводине, с тим циљем и пишемо овај рад, да о Русинима не сазнајемо само од њих самих него да подстак- 
немо друге истаживаче да се заинтересују за русинску историју, језик, књижевност и обичаје. Исто тако наш циљ је и да мотивишемо Русине за још приснију и слободнију културну и просветну интеракцију са већинским становништвом и другим мањинским заједницама у Војводини и целој Србији.

У палеославистици је позната чињеница да су источнословенска племена најдуже од свих словенских племена живела и развијала се заједно и говорила истим језиком све до 14/15. века. Етнички Русини воде порекло од источнословенских племена која су насељавала територију источних Карпата у 6. и 7. веку. Источни Словени су тада живели у племенском друштву, племена су се обједињавала у племенске савезе на чијем челу је био кнез. Окупљајући се око племена Рус у 9. веку настаје и прва држава источних Словена - Кијевска Русија (Киевская Русь). Од многобројних назива племена, која су тада постојала, до данас су дошли називи само неких словенских племена, а за Русине се сматра да су настали од Тивераца, Улича, Белих Хрвата (Рупосова, 2012: 91).

Етноним Русин има древни корен, поред њега који је преовладао као назив народа, срећу се и називи Угрорусини, Угроруси, Карпаторуси, Карпатскоруски народ (Рупосова, 2012: 91), Руски народ, Рутени ${ }^{1}$ (сматра се латинизираном верзијом, распростањена је на енглеском говорном подручју), од 20. века се појављују и термини Украјинци-Русини/Русини-Украјинци, помињу се у историјским документима и називи Руснаци, Руси као и Малоруси, на нашим просторима поред Русин, неки истраживачи или чланови русинске заједнице користе и назив бачко-сремски Русини (бачко-сримски Руснаци $)^{2}$, поготово после распада бивше Југославије. Хорњак (2007, 28) разрађује тему и прецизира «за себе су говорили да су: Рутени, Русини, Русичи, Руснаци, Рушњаци, Лемки, Бојки, Хуцули, Хорњаки, Цотаки, Хутораки, често и уз назнаку припадности већинском народу - Угро (Мађарски) Русини. Мало-Руси, Лемко-Руси, Лемко-Пољаци, Галицијани (...) јужнословенски Русини, амерички (канадски) Русини,

\footnotetext{
1 О етнониму и пореклу и историјским условима настанка етнонима Русин видети: Суляк 2007. и Суляк 2015.

2 Видети: Хорњак 2007, Жирош 1997.
} 
Русини католичке (грко-католичке) вероисповести, Русини православне вероисповести». Сличне етнониме помиње и Латјак (Латяк, 2017: 304) као што су Лемки, Украјинац (Українец), Русин, Руснак, Карпаторус, Угрорус, у Југославији је то Руснак, Русин, а Јеремић (1928) Бачки Руси.

Руски извори ауторство етнонима приписују императору Александру Трећем (владао је Русијом од 1881. до 1894. године), наиме на молбу да се прими локално становништво у састав Русије под именом Руси, император није дао одобрење за то и предложио је етноним Русини. По другој верзији становништво региона се назива Русинима још од средњег века (Рупосова, 2012: 91-92).

Савремени Русини насељавају западни део Закарпатске области у Украјини, североисточну Словачку, а до Другог светског рата насељавали су и југоисток Пољске. Део Русина данас живи у расејању куда су се последњих неколико векова иселили из савремене Украјине - у Мађарску, Србију (у Војводину, где им је језик признат као један од званичних језика администрације), у Канаду, САД, Хрватску, Аустралију и Русију.

Роберт Магочи (Magocsi, 2015: 1) даје табеларни приказ колико Русина има у званичним пописима, а колико је процењено да их, заправо, има широм света. Подаци се односе на 2012. годину (превод наш).

Табела 1. Русини у свету - службени подаци и процена.

\begin{tabular}{|l|l|l|}
\hline Држава & службени подаци & процена \\
\hline Украјина & 10.100 & 853.000 \\
\hline САД & 12.900 & 620.000 \\
\hline Словачка & 55.500 & 130.000 \\
\hline Румунија & 250 & 35.000 \\
\hline Србија & 14.200 & 20.000 \\
\hline Канада & & 20.000 \\
\hline Република Чешка & 1.100 & 10.000 \\
\hline Мађарска & 3.900 & 6.000 \\
\hline Хрватска & 2.300 & 5.000 \\
\hline Аустралија & & 2.500 \\
\hline укупно: & 110.750 & 1.762 .500 \\
\hline
\end{tabular}


Према подацима, које је презентовао Магочи, и његове прецене, Русина у свету има око два милиона - а за Србију, односно Војводину, извели бисмо закључак, на основу увида у пописне податке, да је цифра стања из пописа и процена - најприближнија, што можемо сматрати још једним показатељем врло позитивног односа

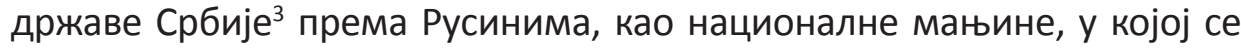
припадници мањине слободно изјашњавају без икакве репресије чак стичући и неке компаративне предности у односу на већинско српско становништво (плаћени дани верских празника - кад се не поклапају са православним (државним), предност у запошљавању у установама националних мањина, покрајинским секретаријатима као и школама са наставом на русинском језику). Хорњак (2007: 25) даје ширу и слободнију процену бројчаног стања и процењује да 60\% Русина живи у карпатским областима Украјине, Пољске, Словачке, Мађарске и Румуније а остатак око $40 \%$ у дијаспори у САД и Канади 650.000 , европским земљама, Аустралији, Новом Зеланду, Јужноафричкој Републици.

Не може се поуздано рећи кад су преци данашњих Русина примили хришћанство. 3бог дугог периода заједничке историје свих Источних Словена, може се ипак претпоставити да су се покрстили у време када је кнез Владимир Кијевски примио хришћанство и прогласио га званичном религијом своје кнежевине 988. године. О том периоду заједничке источнословенске историје и примања хришћанства пише Ољејаров (Олеяров, 1981: 15-17). У науци има и других мишљења, тако Суљак (Суляк, 2015: 267) сматра да је процес примања хришћанства ишао у три етапе: први од 1. до 8. века када су Словени били у кон-

3 О посебном и позитивном односу Србије према Русинима Хорњак (2007: 26) каже: Ниједан владајући режим, ниједан друштвено-политички систем који су се смењивали у региону - царски руски, пољски и хасбсбуршко-аустроугарски до Првог светског рата, демократски у Масариковој Чехословачкој 1918-1938, националсоцијалистички Хитлеров у окупираним областима Пољске, Чехословачке и Украјине 1939-1944, диктаторски режим адмирала Хортија у Мађарској и генерала Антонескуа у Румунији, као ни Стаљинов совјетски 1945-1991, нису успевали да нађу решење за русинско питање. (...) Једини изузетак у том погледу представља Краљевина Срба, Хрвата и Словенаца у којој Русини, у складу са париским мировним споразумима којима је завршен Први светски рат и Статутом Друштва народа признати 1919/20. као мањина словенског порекла, са статусом и правима прилагођаваним времену и друштвено-политичким уставно-правним и политичким променама до данас (изузев за време Другог светског рата и окупације 1941/45.)». 
тактима на северо-западу Црноморског региона са античким светом, друга етапа је повезана са мисионарском делатношћу св. Константина и Методија (9. век) и трећа етапа се односи на завршницу процеса христијанизације за време кнеза Владимира.

Савремени Русини су гркокатолици или унијати. У русинским црквама се служи по православним обичајним правилима, следи се византијска литургијска традиција али се признаје папа као верски поглавар. После раскола јединствене хришћанске цркве 1054. преци данашњих Русина су остали верни источном обреду - православни, међутим, живећи вековима под притиском Римокатоличке цркве и пропагираног екуменства (поновно уједињење хришћана али под приматом папе и Католичке цркве) одолевајући Фирентинској, Брестовској унији на крају ипак приступају Ужгородској унији 1646. године ${ }^{4}$. Унија је чак дуго времена била и тајна међу самим Русинима, а по речима Рупосове (Рупосова, 2012: 92) православље се официјално држало напоредо са унијом до 1733. до смрти последњег православног епископа.

Код Словена је у блиској вези са религијским питањима и језик. Преци Русина, као што је већ поменуто су говорили до 14/15. века заједничим староруским језиком (древнерусский язык) или општеисточнословенским. Тек од 14/15. века се тај заједнички језик свих источнословенских племена почињао диференцирати и издвајати у три правца који ће касније постати руски, украјински и белоруски. У науци су се дуго водиле полемике да ли је русински - дијалекат украјинског или руског или самостални језик. У цркви се користио црквенословенски, по доласку у ове крајеве Русини развијају кроз векове, оформљавају и напослетку кодификују “русински језик Југославије" 1974. године који се среће под разним називима: панонски дијалект, бачванско-сремски (бачванско-сримски) дијалект, панонско-русински језик, бачвански русински језик, војвођански језик, руски језик, јужнорусински језик, руська бешеда...

Овај кодификовани језик је по структури ближи западнословенским ${ }^{5}$ језицима него источнословенским јер је настао под великим

$4 \quad$ О преласку на на унију видети: Олеяров 1981: 40.

5 Као западнословенски језик се изучава на Филозофском факултету у Новом Саду на Одсеку за славистику. 
утицајем словачких говора, али се и активно попуњава позајмљеницама из српског језика и других јужнословенских језика (Рупосова, 2012: 92). Ова варијанта русинског - језик војвођанских Русина се најинтезивније развија у поређењу са другим дијалектима русинског језика будући да има и књижевну норму и различите жанрове књижевности, граматику, речник и вреди посебно истаћи - Одсек за русинистику у Новом Саду (1972. Лекторат, а од 1981/2. Катедра, од 2002. Одсек). Дуличенко овај језик подводи под термин словенски књижевни микројезики (Дуличенко, 1981) а по аералном принципу југословенско-русински он свртава у острвске микројезике (Дуличенко, 2017:41) због своје изолованости. Пипер га сматра најразвијенијим словенским књижевним микројезиком (Пипер, 2004: 31). О употреби русинског језика у службеној сфери у Војводини опширно је писано: Катунин 2015, 2016.

О досељавању Русинау “новикрај” једостаписано, најпријемчивије је о томе писао Хорњак ${ }^{6}$ (2006: 30-34) чије најзначајније податке, у прилагођеном облику, презентујемо у раду. Врло је неуобичајен начин досељавања Русина у данашњу Војводину, за кратак период је досељавање завршено. Русини су се доселили између 1745. и 1765. из североисточних крајева Угарске која је тада била у саставу Хабсбуршке монархије, то је територија данашње западне Украјине. Треба напоменути да су прве групе Русина "слободног статуса" дошле самоиницијативно, у потрази за бољим животом7. По њиховом доласку, царске власти су дозволиле насељевање до 200 породица "Рутена слободног статуса, византијско-католичког обреда" унијата у Бач Керестур, данашњи Руски Крстур и до 160 породица у данашњу Куцуру. Године 1765. организовано насељавања је практично завршено, иако је појединачних долазака било и наредних деценију-две. Процењује се да се укупан број досељеника кретао између 2.000 и 3.000.

Полако прилагођавајући се животу у равници број Русина се на овом поднебљу увећавао, тако да их је у првој деценији 19. века било више од 6.000, а половином 19. века преко 7.500. Од тога у Руском Крстуру око 4.300, у Куцури око 2.500, на подручју Новог Сада и

6 Михајло Хорњак је био каријерни дипломата, југословенски амбасадор у Кини и Јапану.

7 О историјским и политичким предусловима за досељење Русина у области данашње Војводине видети: Фейса 2013. и Fejsa 2014. 
Шајкашке око 600 и на подручју Срема и источне Славоније, од Шида до Вуковара и Осијека око 1.200.

Досељеници су и у „новом крају“ до 1918. били изложени политици асимилације (мађаризација) као и њихови сународници у „старом крају“, али су се успешније одупирали захваљујући бољим економским условима, животу у компактној заједници (Руски Крстур, Куцура), као осећају да су „своји међу својима“ у словенској средини, због слободног деловања Цркве и свештеника и могућности и жеље за образовањем.

Распадом Аустро-Угарске и прикључењем Војводине Краљевини Срба, Хрвата и Словенаца 1918. (не треба заборавити да је су се за присаједињење изјаснили и представници Русина у Великој скупштини Војводине), почео је нови период у животу бачко-сремских Русина. У новој држави су први пут у својој историји били признати као мањина словенског порекла са правима на нивоу тадашњих схватања, за разлику од њихових сународника који су у „старом крају“, подељени између неколико држава на признање чекали до великих политичких светских потреса - распада Совјетског Савеза, а неки то нису добили ни до данас.

Период између 1918. и 1990. (са изузетком периода мађарске окупације 1941-1944 ${ }^{8}$ ) испуњен је окончањем процеса етничке-националне хомогенизације, стандардизовања језика, развојем образовања на матерњем језику, формирањем националне интелигенције (учитеља, професора, лекара, адвоката, итд), оснивањем првих културно-просветних организација, штампањем првих новина, уџбеника за основно образовање, часописа за децу, књижевних-прозних, поетских и драмских дела, радом аматерских културних и фолклорних друштава, позоришта, итд, а у оквиру државне политике националне равноправности донео је нове могућности за развој и афирмацију историјског наслеђа, културног развитка и образовања, као и за равноправно укључивање у све друштвене токове, што је резултирало развијањем и учвршћивањем образовних, културних, информативних, уметничких, спортских и других институција са националним предзнаком - кад је реч о националним мањинама без преседана у свету.

8 О периоду Другог светског рата и учешћу југословенских Русина у рату - видети: Буркут 2011: 37-51. 
Период између 1990. и 2000. године, био је испуњен бројним искушењима и тешкоћама (опште прилике - прво ограничавање локалне самоуправе, укидање општина Руски Крстур, Куцура, Ђурђево, сиромаштво, исељавање, на крају рат и распад СФРЈ који је оставио део русинске заједнице у Хрватској и Босни - озбиљно су угрозиле опстанак и рад основних институција.

Промене остварене у октобру 2000. године донеле смиривање у друштвеним кретањима и односу према националним мањинама, али не и неопходну стабилизацију на прокламованом путудемократизације и укључивање у процес европске интеграције. Последње две деценије су обележиле транзиција и привредна девастација уместо дуго очекиваних евроинтеграција. Републички Закон о заштити права националних мањина (Закон $2002^{9}$ ), донет у овом периоду, постављен на принципима „позитивне дискриминације“ мањина представља значајно достигнуће, оформљен је Национални савет русинске националне мањине. Постојеће институције настављају свој рад у лимитираном обиму због оскудних материјалних околности. Исељавање становништва, из балканских држава се наставља, ниједна нација, ниједна држава у последње време не одољева томе.

Кад се погледа у прошлост, долази се до закључка да су бачванско-сремски Русини, иако им ни овде није увек било лако (делећи често злехуду судбину већинског народа) боље прошли од својих сународника који су остали у „старом крају“, подељени између неколико државних заједница, изложени асимилацији, да би данас у неким земљама били сведени на безначајни број, без биолошке моћи за ревитализацију, подсећајући тиме на Горњолужичке и Доњолужичке Србе у Немачкој.

\section{Установе војвођанских Русина}

Црква као верска установа. Са првим групама досељеника долазили су њихови свештеници гркокатоличке (унијатске) цркве али и православне вере, са знањем словенских дијалеката, као и мађарског и латинског, по доласку су брзо учили и српски. Они су окупљали вернике у

9 После овог Закона, донети су и закони 2009. и 2013. 
оквиру црквене општине, упућивали их на решавање егзистенцијалних проблема, водили књиге рођених, венчаних. Као и код других Словена, први школовани људи су долазили из црквених редова, а у 18. и 19. веку су и најобразованији људи били свештена лица. Свештеници су отворили процес културне хомогенизације ове заједнице одвојене од главнине свог народа, положили основе писмености на народном језику, кодификовању књижевног језика (др Габријел Костелник, Граматика бачванско-руског језика, Сремски Карловци, 1923), прихватању моралних норми заснованих на очувању породице и упућивању на поправљање живота вредним радом (Хорњак, 2007: 34).

Цркве као установе културе. Међу русинским црквама се посебно истичу два здања: Русинска гркокатоличка црква у Руском Крстуру у општини Кула је саграђена 1784. године, после мање, старије, од плетера, покривене шиндром (1753). Имала је све битне одлике црквене архитектуре краја XVIII века на овом подручју (МилановићЈовић, 1988: 142). Коначни, данашњи изглед добила у обнови 1836. године. Важно је напоменути да је данас Руски Крстур центар Гркокатоличког апостолског егзархата у Србији, а тиме је ова црква постала катедрална, саборна црква. Ова црква, која је изграђена у духу класицизма и посвећена је Преносу моштију Светог оца Николаја (у русинској верзији Миколаја), налази се под заштитом Републике Србије као споменик културе од великог значаја. У унутрашњем уређењу се посебно истиче богата резбарија иконостасне преграде - рад познатог дрворезбара Аксентија Марковића из 1791. године.

Иконостаси у грко-католичким црквама у Бачкој потичу из сликарске радионице Арсенија Теодоровића (Milanković-Jović, 1988: 143) ${ }^{10}$. У каснијим годинама - зидну декорацију осликао је 1936. године Миленко Ђурић. Између 1961-1963. године обављена је рестаурација иконостаса. Конзерваторски радови су изведени 1972. године.

Арсеније (Арсен, Арса) Теодоровић, рођен је у Перлезу или Новом Саду 1767. или 1768 , умро 1826. у Новом Саду. Студирао је на Академији уметности у Бечу шест година, населио се у Новом Саду и потписивао се “академски молер". Од момента кад упознаје знаменитог Србина, просветитеља Доситеја Обрадовића, почиње његов рад на културном и уметничком препороду аустријских Срба. Највише времена је уложио у осликавање икона (осликао је 26 иконостаса) али је познат и као врстан портретиста (познати су његови портрети Доситеја Обрадовића, Аврама Мразовића и др. (Медаковић, 1965: 464). О Арси Теодоровићи више: Симић 1965. 
Русинска гркокатоличка црква Светих апостола Петра и Павла у Новом Саду се налази на углу улица Јована Суботића и Светозара Милетића. За разлику од крстурске цркве, коју су осликавали и резбарије радили српски уметници, новосадска црква је имала мало другачију историју. Изградња богомоље је почела 1820, или по Milanković-Jović (1988: 142) «збудована» је 1822. године и у архитектонском облику с уклапа у тип православних цркава прве половине XIX века, какав ауторка константује код низа цркава у Шајкашкој.

Црква је завршена тек 1847, а 1997. црква је прославила 150. годишњицу свог постојања када је у потпуности реновирана ${ }^{11}$. Тада је одлучено да се на прочеље храма поставе три иконе урађене у техници мозаика: икона Св. Павла, икона Св. Петра и централна икона Исуса на плаштаници са крстом изнад главе. Ове три иконе заједно сачињавају величанствени триптих, које је израдио будимпештански професор ликовне уметности Ласло Пушкаш. Пушкаш је иконе израдио у византијском стилу, у техници мозаика ${ }^{12}$ приликом чега је користио специјално израђене делове од муранског стакла ${ }^{13}$ из Венеције.

Поред цркве за словенске народе су једнако важне и школе. Историјат школства код Русина је врло интересантан. Он не почиње доласком на територију данашње Војводине него је започет још у старом крају, тако је нпр. у Мукачеву (данашња Украјина, Закарпатје) радила Богословска школа, у којој су се образовали учитељи, ова школа је пресељена у Ужгород (Салонтаји, 2007:6).

Школе са наставом на матерњем језику установљене су у првим годинама по досељавању у Бачку, у Руском Крстуру 1753 , Куцури 1765, Шиду 1818, и Новом Саду 1829, касније у Ђурђеву и другим местима у којима су живели Русини у Бачкој, Срему и Славонији. Биле су то конфесионалне школе „тривијалке“ у којима се на матерњем језику учило читање и писање, рачун и веронаука.

11 Читаву обнову цркве, 1997. године, финансирала је породица Колесар из Новог Сада.

12 За израду мозаика он је употребио чак 35 боја, што чини својеврсни куриозитет, јер су нпр. мозаици у Св. Софији у Цариграду рађени у 30 боја и сматрају се најлепшим на свету.

13 Стакло је направљено у чувеној фабрици Олсони на острву Мурано у Венецији, фабрика је позната и по томе што је испоручила стакло за мозаике на згради Уједињених нација у Њујорку. 
После пресељења у Бачку, односно у Руски Крстур (1745), Русини су, у тесној вези са црквеном општином, 1753. године основали своју школу. У овом типу школа су децу обучавала свештена лица и то: верским наукама, хришћанској правди, моралу итд. Училе су се и молитве, катехизам, библија... и то превасходно напамет. Касније, доласком школованих учитеља, све више се поред верских наука учи и читање и писање (Папуга, 2000:30).

Подаци даље говоре да је основна школа у Руском Крстуру прошла у свом веку више раздобља: период конфесионалне ${ }^{14}$ школе од 1753. до 1888. године, затим комуналне (општинске) од 1888. до 1899. и државне од 1899. до 1918. године. Између два светска рата школа је била државна. После 1944. године, то је била најпре четвороразредна основна школа, а касније, педесетих година потпуна осмогодишња школа, каква је и данас. Након ослобођења 1945. године, основна школа у Руском Крстуру наставља рад и, својствено тадашњем времену, укључује се у наставу као Народна школа на русинском језику. У фебруару 1945. отворена је Државна реална гимназија - прва гимназија у историји Русина. Гимназија је радила до 1949. када је трансформисана у основну школу, а 1970. године гимназија поново наставља са радом и то прво као истурено одељење Гимназије „Вељко Влаховић” из Врбаса, а затим као самостална. Ирина Папуга у изузетној монографији о русинској гимназији „Петро Кузмјак” (2000: 210) даје прецизан преглед развитка гимназије и помиње три датума, три годишњице гимназије: 1945. кад је први пут отворена, њу назива Прва гимназија, потом 1970. као Друга гимназија и 1990. као Трећа гимназија када је изменама школских прописа поново враћена гимназија, што је омогућило да тадашња средња школа прерасте у гимназију и да се 1990/1. трећи пут у свом развоју упише једно одељење гимназије са наставом на русинском (19 ђака) и једно одељење са наставом на српском језику (34 ученика).

14 Конфесионалне школе су биле у тесној вези са црквеним општинама, биле су претежно сиромашне јер су их финасирале црквене општине. Конфесионалне школе су оснивале и одржавале поједине конфесије, тј. верници, па су тако и добиле назив «конфесионалне школе» или вероисповедне школе, а понегде и црквене и парохијалне (Папуга, 2000: 30). 
Образовни центар „Петро Кузмјак” основан је 1977. године, а 1987. отворен је нови, савремено грађен и уређен објекат и створени су услови за васпитно-образовни рад на русинском језику, од основног па све до усмереног образовања. Данашња модерна Основна школа "Петро Кузмјак" има преко 400 ученика. Гимназија има једно одељење на српском и једно на русинском језику, а такође и једно одељње на смеру туристички техничар што је све заједно око 200 ученика. У оквиру школе успешно функционише и врло добро опремљен средњошколски дом, сала за физичко васпитање и отвореним спортским теренима. Школска библиотека има око 14.000 књига, док су мултимедијалне учионице и кабинети све опремљенији и свеобухватнији за извођење наставе радионичког и иноваторског типа. Школа се налази на адреси Русинска 63, Руски Крстур. Свакако је важно истаћи да је гимназија на русинском језику једина таква гимназија на свету и то је чине уникатном школом како у држави тако и у свету.

\section{Одсек за русинистику Филозофског факултета Универзитета у Новом Саду}

Русинистика је по природи ствари нераскидиво везана за славистику (русистику), посебно што се тиче њеног факултетског развитка из које се издваја као млађа дисциплина, будући да Катедра за руски језик и књижевност (с овим или другим називом) на Филозофском факултету у Новом Саду постоји и ради пуних 56 година. Услед друштвене потребе за развојем националних језика и култура Факултет 1972. године доноси одлуку о формирању Лектората за русински језик и књижевност у оквиру Катедре за руски језик и књижевност. Тада је и наставни програм студија русинистике обогаћен русинским као изборним словенским језиком, поред пољског и словачког (Мирић, 2012: 88). Убрзо потом 1. децембра 1972. године у звање лектора за русински језик изабран Јулијан Рамач. Три године касније 1. децембра 1975. године за асистента-приправника за русинску књижевност изабран је Јулијан Тамаш. Надаље је Лекторат издвојен из Катедре 1979, настављајући свој рад као посебна студијска група (Мирић, 
2012: 88). У априлу 1981. године при Институту за педагогију основана је Студијска група за русински језик и књижевност и за њеног шефа именован је мр Јулијан Тамаш. Студијска група уписује прве студенте школске 1982/82. године. Докторатом из књижевних наука и избором Јулијана Тамаша за доцента за Русинску књижевност оснива се Катедра за русински језик и књижевност (1983). Следећа реорганизација је дочекала 1993. годину кад је Катедра за русински језик и књижевност поново у заједници са Катедром за руски језик и књижевност, а поново им се се путеви раздвајају 1998. да би 2002. обе биле преименоване у одсеке и наставиле самосталан рад (2012: 89).

Специфичности овога Одсека су релативно мали број студената, због мале русинске популације у Војводини и свету. По Анамарији Рамач Фурман (2015: 2) русински језик на Одсеку не морају да студирају само припадници русинске националне заједнице, него су студије отворене за све који желе да се упознају са једним специфичним језиком. У досадашњем раду било је случајева да су студије уписивали студенти са минималним знањем русинског, али су до краја студија русински у потпуности савладали. Склоп околности је такав да су наставници морали прво да научно опишу свој предмет проучавања, а тек потом да га предају на универзитетском нивоу (Римар, Папуга, 2015: 22). Из тога је проистекло неколико обављених капиталних послова за русинистику и славистику: историја русинске књижевности, историја Руског Крстура, живот и дело Гаврила Костељника, историја Русина, граматика русинског језика, речници русинског језика (двосмерни према српском), конфронтације русинског са енглеским језиком, украјинска књижевност између Истока и Запада и слично (Рамач Фурман, 2015: 2).

Структура запослених на Одсеку за русинистику је следећа: др Јанко Рамач, редовни професор, др Михајло Фејса, редовни професор, др Стеван Константиновић, ванредни професор, мр Ксенија Сегеди, виши лектор, мр Анамариа Рамач Фурман, асистент, ма Александар Мудри, асистент. Спољни сарадници: др Јулијан Тамаш, ред. проф. у пензији (редовни члан Украјинске академије наука и уметности Украјине у Кијеву од 1997 и редовни члан Војвођанске академије наука и уметности од 2004, председник ВАНУ 2004-2008), др Људмила Поповић, ред. проф. Филолошког факултета у Београду. 
Оно што је важно напоменути да Одсек за русинистику припрема кадрове за рад не само у школским, образовним већ и информативним и културним установама, подједнако на русинском и српском језику (Хорњак, 2007: 56).

Руска матка (Матица русинска) је основана 28. децембра $1990^{15}$. у Руском Крстуру и од тог доба несметано ради на окупљању заједнице али и националног и културног наслеђа, кроз низ активности и манифестација којима је покровитељ и организатор (Папуга 2005: 213). Обележавање 200 година (1947) као и 250 година од досељавања (1995) у Бачку, две највеће манифестације у том периоду, представљало је својеврсну историјску смотру материјалних и културних достигнућа русинске заједнице, потврду њене виталности и донело нови полет настојањима усмереним на афирмацију историјског наслеђа у условима бољим него у прошлости ${ }^{16}$.

Руска матка је организована на територијалној основи, у пет месних организација: у Руском Крстуру, Кули, Куцури, Врбасу и градској организацији у Новом Саду (Папуга 2005: 213, превод наш) прилагођеној остваривању програмских циљева. Поред Управног одбора са седиштем у Руском Крстуру, постоје месни одбори у местима са русинским становништвом. Управни одбор, председник, четири потпредседника, генерални секретар, руководиоци месних организација и секција представљају руководство Руске матке. Учлањивање у друштво је добровољно, на личној или породичној основи, отворено за припаднике свих националности, активност и рад на програмским опредељењима није условљена учлањивањем. Финансирање рада Руске матке је из доприноса чланова, донација и помоћи друштвене заједнице, највећи део рада одвија се на добровољној основи и личном доприносу, нико за свој рад не прима финансијску накнаду. Седиште организације Руска матка је у Руском Крстуру, Маршала Тита 59 председник главног одбора је Ђура Папуга.

15 Овај датум се узима као датум оснивања, али треба напоменути да је пре тога једно кратко време већ постојала Руска матка у периоду 1945-1948, када је због политичке климе у резулуције Информбироа, донета одлука о сапораспуштању. О томе више: Хорњак 2007: 46.

16 Покушаји да се обележавање 250. годишњице досељавања претвори уплебисцитарно изјашњавање за украјинску националност доживели су неуспех (Хорњак 2007: 46). 
Руска матка је и један од оснивача Светског конгреса Русина са седиштем у Прјашову, Република Словачка, као и придружени члан Организације европских недржавотворних народа, са седиштем у Кану, Француска. Руска матка је члан форума Светски конгрес Русина од његовог оснивања 1991굴. На скуповима Светског конгреса Русина изражавано је једнодушно признање тадашњој Југославији и Србији на њиховој политици равноправности и поштовања права националних мањина ${ }^{18}$ стога су власти у претходном периоду благонаклоно гледале на ангажовања у раду Светског конгреса Русина, јер је у конкретним унутрашњим и међународним околностима то корисно са становишта афирмације политике према националним мањинама.

Дом културе у Руском Крстуту је дуго година био стожер и место окупљања и културних манифестација војвођанских Русина ${ }^{19}$. Основан је 1946. године годинама представљајући централну институцију око које су се окупљали домови културе и аматерске културно-просветне, фолклорне, музичке и позоришне организације (Жатва, Куцура, Тарас Шевченко, Ђурђево, Карпати, Врбас, Нови Сад, Шид и др). У периоду прекида рада и постојања Руске мате, Дом културе је преузео већину активности и из домена рада данашње Матке. Основни облик рада и организовања су аматерска културно-просветна друштва у којима се негује народно стваралаштво (фолклорна друштва, хорови, музички састави, драмске, рецитаторске секције, библиотеке, читаонице и уметничке колоније), као и спортске организације и клубови, који у континуитету раде од 1945. године а многи и раније од 20-тих година 20. века као што је фудбалски клуб Русин у Руском Крстуру, основан 1923.

Хорњак (2007: 57) истиче да је од посебног значаја за очување националног и културног идентитета представља чињеница да русин-

17 Светски конгрес Русина, као заједнички форум русинских заједница у свету, основан је на платформи окупљања и сарадње у циљу очувања и унапређења културног наслеђа и обезбеђења мањинских права Русина у земљама у којима живе. У раду Конгреса учествују представници русинских заједница из европских и прекоморских земаља. русинске заједнице на њиховом доприносу јачању осећања заједништва русинских заједница у свету. 
ска заједница ангажовањем сопствених кадрова обезбеђује активност својих институција, аматерских и професионалних од основног до универзитетског образовања, информисања, издаваштва, музичко-сценском стваралаштву итд.

Адреса Дома културе је Руснинска 75, Руски Крстур, директор је Јоаким Рац, тренутно има пет запослених, правни статус је установа културе, начин финансирања је из буџета СО Кула, као и преко пројеката Министарства културе РС и покрајинских секретаријата, локалне самоуправе, Националног савета русинске националне мањине. На истој адреси се налази и:

Позоришни живот се код Русина одвија на аматерској основи, ансамбл се окупља по пројектима, хонорарно (Нађ Аћим, 2004/5: 119). Највећи домет у позоришном животу достиже позориште „Ђађа“ (Русински народни театар Петро Ризнич „Ђађа“) са сценама у Руском Крстуру и Новом Саду. Прва позоришна представа на русинском је изведена 1913. године у Куцури. Театар је основан 1970. и има улогу професионалног позоришта за русинску народност у Војводини ${ }^{20}$. За време свога рада Театар је на репертоару имао преко 130 премијера, аутора светске и домаће драмске литературе. Театар „Ђађа“ редовно учествује, са запаженим успехом, на свим покрајинским и републичким позоришним аматерским фестивалима, као и на међународним фестивалима у Украјини, Словачкој, Чешкој и Мађарској.

После ослобођења у Другом светском рату, почела је да ради и прва русинска гимназија у фебруару 1945. године у којој се школовала русинска интелигенција. Управо међу том интелигенцијом се појавила идеја и створена је иницијатива да се публикују прогресивне народне новине на русинском језику, које би русинску народност обавештавале о свим важним догађајима у слободној земљи збратимљених

20 У Руском Крстуру 18. августа 1969. године окупили су се представници покрајинске власти са Русинима да би расправљало о проблемима театралног аматеризма и о другим питањима из области културе Русина. Уводни говор је имао Ђура Папрагаји, у коме је истакао да су сазрели услови за поступну професионализацију позоришног рада с циљем отварања Русинске драме у оквиру СНП у Новом Саду. Представници власти нису били ради да прихвате ову сугестију и предлог, али су истакли спремност да подрже театрални аматеризам с циљем да се тзв. Аматерски театар оспособи за сличну функцију коју имају професионални театри (Латяк, 2018: 118). 
народа и народности. Тако је 15. јуна 1945, почело штампање првих новина на русинском језику које су добиле назив Руске слово а штампане су се у локалној штампарији (Латяк, 2017: 233. превод наш). Прву редакцијску групу Руског слова су чинили: Штефан Чакан, Евген Планчак, Евген Џуна, Јаша Баков, Гавријил Нађ и Ђура Биндас, а рад је био на бесплатној основи из ентузијазма (Латяк, 2017: 234).

Новинско-издавачко предузеће ${ }^{21}$ Руске слово је од оснивања 1945. деловало као обједињено новинско-издавачко предузеће са сопственом штампаријом, редакцијом недељника Руске слово и свих издања на русинском језику, оснивачка права је имала Скупштина АП Војводине. Поред недељника Руске слово, у првим послератним годинама, обновљено је издавање и годишњег алманаха Руски народни календар (штампан први пут 1920, угашен 1940, обновљен 1946. спојен са црквеним годишњаком Дзвони 2003), часописа за децу Заградка (1937-1941), часописа за литературу и уметност Шветлоси, Литературне слово као недељног додатка Руском слову, касније и часописа за омладину Мак, књижевних дела русинских аутора и превода са других језика, уџбеника за основно образовање на матерњем језику, превода закона на русински језик, итд. Године 1967. Новинско-издавачко предузеће Руске слово је пресељено у Нови Сад у зграду Новинско-издавачког предузећа Дневник (адреса Булевар ослобођења 81/7, где се и штампа, а данас се тамо налази и Новинска агенција Рутенпрес. Редакција за издавање уџбеника је припојена Покрајинском заводу за издавање уџбеника (Републичком заводу за издавање уџбеника 1991), штампарија је остала у Руском Крстуру као самостално графичко штампарско предузеће (данас приватизовано). У издању НИП Руске слово у читавом периоду од 1945. до данас штампано је у просеку годишње пет до шест наслова, претежно из књижевности, историје и језика, русинских аутора и превода, док је редакција за издавање уџбеника, у саставу НИП Руске слово и касније Покрајинског односно Републичког завода обезбеђивала уџбенике за потребе наставе на нивоу основног образовања на матерњем језику, према програмима Републичког министарства просвете и образовања (Хорњак 2007: 54-55).

21 Касније је преименовано у Новинско-издавачку установу - како данас и на њиховом логу стоји. 
Оснивачка права Руског слова су 2004/5. са Скупштине АП Војводине пренета на Национални савет.

Недељник Руске слово излази једном недељно, штампа се у око 1.300 примерака, сви примерци се продају претплатом, као и највећи број свих издања на русинском језику. Издавачка делатност књига заузима значајан део продукције Руског слова. У периоду од 2007. до 2017. за десет година је публиковано 79 наслова у издању Руског слова, што самостално што као суиздавача. Насупрот нашем првобитном очекивању да ће преовладати тематика из историје и културологије Русина као и научни радови универзитетских професора, установили смо другачију реалност: кратке форме (поезија, бајке, приповетке) намењене деци и младима су били у средишту пажње уредништва. Наша претпоставка је да начином одабира наслова и аутора овај издавач жели да привуче велики и широк круг корисника, посебно младе. Оно по чему се Руске слово посебно истиче је и подршка ауторима млађе и средње генерације због публиковања њихових оригиналних дела поезије, приповедака, бајки и сл. Језичке, лингвистичке књиге и монографије научног типа и речници су остављени другим издавачима.

Руске слово зналачки и допадљиво бира наслове и ауторе и следи за интересовањима широког аудиторија правећи једну врсту баланса између жеља, потреба и могућности русинске националне мањине у Војводини.

У редакцији Руског слова има тридесетак запослених, седиште је у Новом Саду, Булевар ослобођења 81/7.

Друштво за русински језик, литературу и културу је основано 1970. са седиштем у Новом Саду у циљу очувања, развоја и стандардизовања русинског књижевног језика, књижевности и културе, издаје годишњак Studia Ruthenica. Окупља око себе широк круг афирмисаних домаћих и страних слависта, историчара и књижевника који се баве питањима русинског и словенских језика и литературе. Својим културно-просветним и образовним радом, као и подршком издавачке делатности Друштво се афирмисало као најзначајнија институција русинска - национална институција и допринело развијању Русинистике као посебне гране Славистике. 
Радови стручњака окупљених око Друштва допринели су томе да књижевни језик бачванско-сремских Русина равноправно стане у ред словенских језика (русински је као књижевни кодификован у периоду од 1924. од 1974. као један од пет језика у службеној употреби у Војводини) (Хорњак 2006: 48).

Друштво има 870 чланова из свих русинских средина, међу којима већи број научника слависта из Русије, Естоније, Пољске, Словачке, Чешке, Мађарске, Шведске, САД, Канаде), као и подружнице у Руском Крстуру, Врбасу, Куцури, Ђурђеву и Шиду. Нема запослених.

Председник Управног одбора је Владимир Салонски, председник Скупштине Друштва је др Јулијан Рамач, седиште је Новом Саду, Војводе Путника 2.

Радио Нови Сад је основан 1949. година, а емисије на русинском почињу да се емитују исте године. Од 1949. до 1955. су углавном емисије говорног типа, а од 1955. до 1966. се прелази на музичке (забавна и озбиљна музика). Русинска редакција је оформљена 1966. и бројала је у свом саставу 7 чланова (Жиром, 2015: 536). У почетку су то, по Жирону (превод наш) биле емисије од по 30 минута: Културна панорама, Емисија за село, Емисија за децу и 30 емисија информативног карактера месечно, тј. 15-20 минута дневно. У периоду од 1991. до 2003. редовни програм је био у трајању од око 5 часова дневно, са претежно културно-информативним и забавно-музичким програмом ${ }^{22}$. Данас се програм емитује на трећем програму РНС и то Јутарњи програм радним даном од 6.00 до 8.00 .

Русинска редакција РТВ је основана 1975. године, са редовним програмом у трајању од 6 часова недељно, културно-информативног и фоклорно-забавног материјала. Данас се емитују две емисије поред Дневника на језицима националних мањина (РТВ 2), Добро вече, Војводино (Добри вечар Войводино) РТВ 2 четвртком од 20.00 до 21.30 и ТВ Магазин недељом у 20.00 у трајању од 60 минута, такође на РТВ 2. Поред побројаних средстава јавног информисања постоје и општинска средства јавног информисања у општинама Кула, Врбас, Жабаљ, Шид и Бачка Топола као радио-програми, новине (Кула) и телевизија (Врбас) и локални интернет-радио Руски Крстур.

22 О Русинској редакцији Радио Новог Сада видети: Латяк 2015: 101-116. 
Национални савет русинске националне мањине се може сматрати једним од најмлађих установа културе Русина, будићи да су национални савети као институције а уједно и највиши органи мањинске самоуправе формирани од стране државе на основу Закона о заштити права и слободе националних мањина 2002. у тадашњој СР. Исте године 2. новембра 2002. године, међу првима је свој Савет основала русинска национална заједница. Због политичких превирања и неслагања унутар Савета, он је распуштен 30. октобра 2004. када је након ванредне електонске Скупштине изабран нови. Од тог доба се устаљује рад Националног савета из године у годину, тако да данас представља највиши легитимни орган самоуправе мањина у РС. Национални савет русинске националне мањине, такође, има и свој Статут као највиши правни акт Национаолног савета, који је донет на седници 6. децембра 2004. и има 55. чланова (параграфа) у којем је дифинисан делокруг рада и начин организовања, рада и управљања Националним саветом. Статутом се регулише, по члану 1, надлежност, организација и начин избора органа, а све у складу са Уставом Републике Србије и Законом о националним саветима националних мањина. Члан 2, дефинише сферу рада Националног савета, по коме он - представља русинску националну мањину на територији РС у области образовања, културе, обавештавања и службене употребе језика и писма, учествује у процесу одлучивања о питањима из тих области, оснива установе, привредна друштва и друге организације из ових област. Национални савет Русина, као и други савети, је добио право и обавезу да континуирано брине и координира остваривање права мањина у области образовања, културе, информисања, службеног коришћења језика и писма (Хорњак 2007: 58-59). Савет се налази у Фрушкогорској 64, у Руском Крстуру.

Од 17. новембра 2014. председник Националног савета је Славко Рац из Новог Сада, поред њега чланова има још 18, свих 19 чланова се бирају се бирају на мандат од 4 године, Извршни одбор има четири одбора и три тела. Одбори су за образовање, културу, обавештавање и службену употребу језика и писма. А радна тела су за омладину, спорт и науку. Национални савет је донео и Националну стратегију Русина у Србији (Виславски и други) на 26 страна у којем се поред осврта на историјат Русина, даје и пресек садашњег стања и предлажу смернице за даљи рад. 


\section{Закључак}

Упознајући се са Русинима као народом који се населио средином 18. века у ове крајеве у потрази за бољим животом и добрим суживотом са словенским народом сличном себи у ослобођеним територијама од Турака, долазећи са својим историјским бременом али и сновима о бољој будућности, можемо закључити, на основу многих истражених података, али и кроз праћење развијања културног и образовног интегритета да су Русини у Војводини наишли на разумевање и добре услове за заокруживање свога посебног идентитета, да су нашли своју нову домовину. У освит прославе стогодишњице формирања Краљевине Срба, Хрвата и Словенаца, нећемо заборавити да су изасланици русинске националности, такође дали свој равноправни глас за присаједињење Краљевини СХС и тако и они учествовали у стварању нове државе, што им Србија, такође, великодушно узвраћа дајући права (школовање, језик, празници) која у неким државама нису успели да остваре ни данас у 21. веку. Наравно, односи ни у Србији нису увек били идеални услед политичких и историјских превирања али су се после периода стагнације или кризе отварала врата новим дијалозима и бољим решењима. Дугогодишња тековина образовног и васпитног система у Војводини је била и развијање разумевања и емпатије према националним мањинама често уступајући њима предност у остваривању већих права него већинском становништву, што се у Војводини никад није доживљавало као проблем. Последње две деценије су довеле до тектонских промена у свим сферама живота становништва целе Србије а тако и Војводине, услед распада државе, економске девастације и као последице великог исељавања аутохтоног становништва свих нација а у исто време и досељавања избеглица и тзв. расељених лица. Успостављена нова реалност може нарушити дуго неговану и стицану равнотежу и толерантност. Модел за фунционисање у Војводини би требало и даље неговати у досадашњем правцу али и освежити сличним позитивним примерима других земаља. Држава Србија би требало да има далекорочну стратегију и план подршке у развијању мултикултуралности, исто тако водећи рачуна и о својим интересима 
(оно што држава финансира, то има право да контролише; да успостави однос одговорности за све судионике мултикултурног дијалога; да даје могућност да се поштује мишљење и рад свих, поготово кроз самофинансирајуће пројекте и иницијативе). С друге стране, по нашем мишљењу, није добро да постоји екслузивитет никог па ни националних мањина у правима на запошљавање, школовање, празновање празника, него је потребно неговати равноправност (обезбедити исте услове за све) и на тај начин избећи проблеме, који би се могли појавити у будућности.

Наша жеља је била да овим радом подстакнемо сарадњу и отворимо ум за међусобно разумевање свих учесника културне и сваке друге интеракције како у Војводини тако и у целој Србији, да будемо спремни да мењамо себе и своје ставове, будемо флексибилни и отворени за сугестије, спремни за учење и упознавање нових језика, сличних и различитих култура, обичаја и сл.

С тим циљем и са том мисијом пишемо и завршавамо овај рад ${ }^{23}$.

\section{Литература}

Буркут, Игорь. „Югославские русины и украинцы во Второй мировой войне (19411945 гг.)“. Русин, №2 (24) (2011): 37-51. Веб. 1. мај 2018.

Виславски, Богдан и др. Национална стратегија Русина у Србији. Веб. 31. март 2018. Дуличенко, А. Д. Славянские литературные микроязыки: Вопросы формирования и развития. Таллин, 1981. Штампано.

Дуличенко, А.Д. „Славянская микролингвистика и славянская микрофилология“. Русин, № 2 (48) (2017): 41-50. Веб. 25. март 2018.

Жирош, Мирон. Бачванско-сримски Руснаци дома и у швеце (1745-1991), том 1. Нови Сад: Грекокатолїчка парохия св. Петра и Павла, 1997. Штампано.

Жирош, Мирон. „Руска редакция Радио Нового Саду од 1966. до 1991“. Шветлоси, рок 63, број 4 (2015): 534-557. Веб. 26. март 2018.

Закон о заштити права и слобода националних мањина. Службени гласник СР, број 11. од 27. II 2002. Народна скупштина Србије, донети закони. Веб. 2. мај 2018. Закон о заштити права и слобода националних мањина. Службени гласник РС, бр.

23 Велику захвалност за помоћ приликом писања рада (на разумевању и разјашњавању многих недоумица са којима смо се сусрети у току писања) дугујем двема мени посебно драгим особама - мр Ксенији Сегеди са Одсека за русинистику у Новом Саду и мр Звонимиру Сакачу из Института за ратарство и повртарство Нови Сад. 
72 од 3. септембра 2009. Народна скупштина Србије, донети закони. Веб. 2. мај 2018.

Закон о заштити права и слобода националних мањина. Службени гласник РС, бр. 97 од 6. новембра 2013. Народна скупштина Србије, донети закони. Веб. 2. мај 2018.

Јеремић, Ристо. „Бачки Руси“. Прилози Летопису Матище српске, св 2 (1928): 49-67. Штампано.

Катунин, Д.А. „Языковые права русинов, украинцев и других национальных меньшинств в законодательстве Республики Сербии“. Русин, №1 (39) (2015): 229-238. Веб. 31. март 2018.

Катунин, Д.А. „Русинский язык и языки других национальных меньшинств в законодательстве Воеводины. Статья 2“. Русин, № 1 (43) (2016): 271-284. Веб. 7. април 2018.

Латяк, Дюра. „Початки Рускей редакциї Радио Нового Саду“. Шветлоси, рок 63, ч 1, (2015): 101-106. Веб. 1. мај 2018.

Латяк, Дюра. Руснаци, том 1. Нови Сад: Руске слово, 2017. Штампано.

Латяк, Дюра. „Пейдзешат роки Драмского меморияла Петра Ризнича Дядї“. Шветлоси, број 1 (2018): 115-120. Веб. 1. мај 2018.

Нађ Аћим, Владимир. „Русинско народно позориште Петар Ризнич Ђађа“. Алманах позоришта Војводине бр 39 (2004/5): 119-120. Штампано.

Мирић, Душанка. „Педесет година рада Катедре за руски језик и књижевност Филозофског факултета у Новом Саду“. Славистика 16 (2012): 87-91. Штампано.

Медаковић, Дејан. „Арса Теодоровић“. Летопис Матище српске 395 (мај 1965): 463-471. Штампано.

Олеяров, Николай Д. Исторія русского народа. Монтреал, 1981. Веб. 15. фебруар 2018.

Папуґа, Дюра. „З активносци Рускей матки у периодзе медзи 7. и 8. шветовим конґресом Руснацох/Русинох/Лемкох“. Русин, 2005, №2 (2) 213-216. Веб. 31. март 2018.

Папуґа, Ирина. Русинска гимназија «Петро Кузмјак». Нови Сад: Дружтво за русински језик, литературу и културу, 2000. Штампано

Пипер, Предраг. Српски између великих и малих језика. Београд: Београдска књига 2004. Штампано.

Римар, Ана и Ася Папуга. „Оддзелєнє за русинистику на новосадским универзитету“. Руске слово рок 71, ч. 22, Нови Сад (5 юний 2015): 22-23. Штампано.

Рупосова, Л. П. „Русины и русинский язык: история и современность“. Электронный журнал Вестник Московского государственного областного универcumema №3. (2012): 91-96. Веб. 24. март 2018.

Рамач Фурман, Анамария. „Оддзелєнє за русинистику“. Руске слово 71, ч. 21, Нови Сад, (29. май 2015): 2. Штампано.

Салонтаји, Паулина. Историја наставе физике у школама у Руском Крстуру. Дипломски рад. Природно-математички факултет Нови Сад, 2007. Штампано.

Симић, Ненад. Непознати сликар из прошлог столећа. Београд, 1962. Штампано. 
Суляк, Сергей. „Русины в истории: прошлое и настоящее“. Русин, №4 (10) (2007): 29-56. Веб. 1. април 2018.

Суляк, С.Г. „Начало христианизации Карпато-днестровской Руси“. Русин, №4 (42) (2015): 267-307. Веб. 21. април 2018.

Фейса, М. „Слово з нагоди 250-рочнїци приселєня Руснацох до Коцура и 100рочнїци першей театралней представи на руским язику“. Русин, № 3 (33) (2013): 84-93. Веб. 1. мај 2018.

Хорњак, Михајло. „Бачко-сремски Русини (порекло, начин живота, положај и права, институцијеиорганизације)“.МихајлоФејса(ур.).Русини=Руснаци=Ruthenians: (1745-2005). 1. Нови Сад: Прометеј, 2007. 23-73. Штампано.

Magosci, Robert Paul. With Their Backs to the Mountains. A History of Carpathian Rus' and Carphato-Rusyns. Budapest-New York: CEU Press. 2015. Veb. 16. februar 2018.

Milanković-Jović Olivera. Umetnost u Bačkoj u XVIII i prvoj polovini XIX veka. Novi Sad: Pokrajinski zavod za zaštitu spomenika kulture; v Ljuljani: Znanstveni inštitut Filozofske fakultete, 1988 (Novi Sad : Talija). Štampano.

Fejsa, M. „The Ruthenian Journey from the Carpathian Mountains to the Panonian Plain“. Rusin, № 2 (36) (2014): 182-191. Veb. 7. april 2018.

\title{
Dragana Savin
}

\section{RUTHENIANS IN VOJVODINA- CULTURAL INSTITUTIONS}

\begin{abstract}
Summary
For over 250 years, the Ruthenians live together with the Serbs and other nations in the territory of today's Vojvodina. In this paper we find out how formed the cultural and national identity of Ruthenians in Vojvodina through establishment and work institution of culture, education and religion. The paper also presents historical data on the origin of Ruthenians, immigration into the so-called. A "new end" and their adaptation to life in a fertile plain.
\end{abstract}

Key words: Ruthenians, Vojvodina, history, institutions, culture, education, religion, national identity 